\title{
Economic viability of different management regimes for Eucalyptus grandis W. Hill stands
}

\author{
${ }^{1}$ Gabriel Paes Marangon, ${ }^{2}$ Paulo Renato Schneider, ${ }^{2}$ Emanuel Arnoni Costa, ${ }^{3}$ Terezinha Bezerra Albino Oliveira, \\ ${ }^{2}$ Jorge Antônio de Farias, ${ }^{2}$ César Augusto Guimarães Finger
}

${ }^{1}$ Federal University of Pampa, Course of Forest Engineering, Avenue Antônio Trilha, 1847, CEP 97300-000, São Gabriel (RS), Brazil.

${ }^{2}$ Federal University of Santa Maria, Department of Forest Sciences, Roraima Avenue, 1000, CEP 97105-900, Santa Maria (RS), Brazil.

${ }^{3}$ Federal University of Alagoas, Agrarian Sciences Center, BR 104, CEP 57100-000, Rio Largo (AL), Brazil.

Correspondence Author: Emanuel Arnoni Costa, Federal University of Santa Maria, Department of Forest Sciences, Roraima Avenue, 1000, CEP 97105900, Santa Maria (RS), Brazil. E-mail: emanuelarnonicost@hotmail.com

E-mail: emanuelarnonicost@hotmail.com

Received date: 23 March 2018, Accepted date: 25 April 2018, Online date: 25 May 2018

Copyright: (C) 2018 Gabriel Paes Marangon et al. This is an open-access article distributed under the terms of the Creative Commons Attribution License, which permits unrestricted use, distribution, and reproduction in any medium, provided the original author and source are credited.

\begin{abstract}
Background: The economic viability of different management regimes of forest stands is one of the most adequate alternatives to assess the risk of investments in forestation. Objective: We evaluate the ideal management regime for consolidated commercial stands of Eucalyptus grandis localized in Rio Grande do Sul, Brazil. Methods: The measured forest stands are located in the Central-Western region of Rio Grande do Sul and the Metropolitan region of Porto Alegre. The economic viability has been considered according to the Internal Rate of Return (IRR), Net Present Value (NPV), Annualized Net Present Value (ANPV), Benefit-Cost Ratio (BCR), and Profitability Index (PI) criteria. Three management regimes were simulated: I) trees with no thinning and clear-cutting at 52.8 months; II) trees with one thinning at 53.0 months and clear-cutting at 85.0 months; and III) trees with two thinnings (52.8 and 85.4 months) and clear-cutting at 121.8 months. Results: Investments in reforestation with Eucalyptus grandis under different management regimes provided economic returns, with emphasis to regime III, which was the most attractive. Conclusion: By according with the viability results that consider the variation of capital value along the management regimes, it was possible to identify the ideal occupation of the site, with control of production and competition levels in line with the maximization of economic profitability.
\end{abstract}

Keywords: silvicultural interventions, economic scenarios, forest planning

\section{INTRODUCTION}

A good management of a forest stand, with objectives defined beforehand, becomes achievable with the correct density regulation. Through techniques of intensive management, it is sought to conduct the forest towards the differentiation of its multiple use, which generates profit throughout the rotation, adding value to the raw material produced for cellulose, paper, furniture, lamination, the construction industry, plywood, among others. The optimization of forest use through intervention techniques throughout its life generates intermediate cash flows, adding high value to the raw material produced (Retslaff $e t$ al., 2016).

The reduction of a forest population density that aims to benefit trees with larger diameters, uniform stems, and steady timber production, is related to the removal of individuals from the stand, which is called thinning (Campos and Leite, 2013). When thinning is performed, it is aimed to the balanced development of the crown and the root system, according to the tree dimensions, since it increases the living space of each tree. When performed in the adequate intensity and at the right time, it allows to improve timber quality, homogenize assortments and increase tree dimensions, without significant loss to production. However, heavy weight thinning can lead to the disproportionate increase in size of the crown and branches, decreasing not only the timber quality but also the forest volumetric production (Scheeren et al., 2004).

As the eucalyptus production at the level of individual tree volume has not been a priority for Brazilian companies, thinning has not been a common practice. Consequently, there are few studies of eucalyptus thinning density in Brazil. However, the response of eucalyptus to different thinning intensities has been studied in several other countries (Nogueira, 2015). Self-thinning is essential for the modern forest management based on density. The self-thinning process derives from the dynamic interaction between growth and mortality of the support in balanced conditions. Nevertheless, despite the dynamic basis for the self-thinning process, it is generally modelled with static data of size density (Trouvé, 2017). Self-thinning is established in forest plantings when tree crowns expand and intercept a greater amount of solar power, leading to an increased competition among individuals as they age, and this process culminates with the domination and death of trees (Schneider, 2015).

One of the most useful applications for planning thinning regimes are the density management diagrams (DMD). They can either be used to determine time and intensity of thinning to achieve the objectives defined for the cutting, or to compare and choose between a group of possible cutting plans. Furthermore, diagrams are a useful tool to understand the dynamics of forest stands and the implications of the various density manipulations to achieve the management objectives. It is important to acknowledge that DMD, as the majority of other growth models, simulate the mean standard growth of a great variety of potential growth trajectories (Farnden, 1996).

The forest activity has a relatively long production cycle, what makes the decision-making process more difficult. Thus, as in any investment, managers need to decide how much to produce (area), how to produce (spacing, management, etc.) e what to produce for, i.e., energy, cellulose or sawmill. In addition to these technical aspects, it is suggested that every decision-making process considers economic-financial aspects, restrictions of production factors, and risks involved in the production process, since the forest investment requires a significant amount of initial capital, which is retained for a long period (Simioni and Hoeflich, 2006).

The inherent factors related to land, such as the dependence on climate associated to risks of pests and diseases, have led some land owners to realize that since it is an activity directly linked to nature, planning and control of operations of an agricultural production system are unnecessary (Marion and Segatti, 2012). However, in an environment where competition tends to increase, assessing the performance of these organizations and intervening to eliminate activities that do not add value to products are essential conditions for any modern company to be a step ahead on competitors (Bornia, 2009). 
Citation: Gabriel Paes Marangon, Paulo Renato Schneider, Emanuel Arnoni Costa, Terezinha Bezerra Albino Oliveira, Jorge Antônio de Farias, César Augusto Guimarães Finger, 2018. Economic viability of different management regimes for Eucalyptus grandis W. Hillstands. Australian Journal of Basic and Applied Sciences., 12(5): 39-46.

In view of what has been exposed, the research question to be approached is how to economically assess the different management regimes of eucalyptus to know the potentialities of financial returns in future investments in this culture. Among the methods that can be applied for this assessment, this study suggests the analysis of economic indicators in which it is aimed to support the decision-making process in an environment of different alternatives and scarce resources. Based on the context of the research question, the aim of this study is to assess and relatively suggest the ideal management regime for consolidated commercial forest stands of Eucalyptus grandis in Rio Grande do Sul, Brazil, considering economic criteria.

\section{MATERIAL AND METHODS}

Study areas:

The stands of Eucalyptus grandis W. Hill measured are located in the Central Western Region of Rio Grande do Sul, and Porto Alegre Metropolitan Region, all belonging to Rio Grande do Sul, Brazil. According to Köppen classification, the climate in the studied regions is Cfa with mean annual temperature of $17.9^{\circ} \mathrm{C}$ and mean annual rainfall of $1826 \mathrm{~mm}$ (Alvares et al., 2013). The soils, which are part of the Rio Pardo mapping unit, are deep, clay, well drained, have a reddish color in nearly the whole profile, and derive from fine silt stones.

Data collection:

Data were obtained from the measurement of the diameter at breast height (DBH) and total height (h) of 1,336 permanent parcels located in different sites and with different ages. For the modelling of the number of trees and ages, 107 and 1193 observations were used, respectively. The 104 average trees, distributed in DBH classes, from stands implanted with different initial spacing (1.0m x $1.5 \mathrm{~m}, 3.0 \mathrm{~m} \times 1.7 \mathrm{~m}, 2.3 \mathrm{~m} \times 2.3 \mathrm{~m}, 2.0 \mathrm{~m} \times 2.0 \mathrm{~m}$, among others), were cubed for volumetric and stem form studies.

\section{Stand density:}

Density and diameter studies were performed with number of trees per hectare and the correspondent mean diameter of trees. For this purpose, the Tang, Meng and Meng (1994) equation was used, expressed as:

$\ln N(t)=\ln S_{f}-\frac{1}{\gamma} \ln \left[\left(D(t) / d_{0}\right)^{\beta_{\gamma}}+\delta\right]$

Where: $\mathrm{N}(\mathrm{t})=$ stand density in time $\mathrm{t}$ (number of trees per hectare); $\mathrm{t}=$ stand age (year); $\mathrm{Sf}=$ maximum stand density; $\gamma=$ self-thinning index; $\mathrm{D}(\mathrm{t})=$ mean diameter of trees in time $\mathrm{t}(\mathrm{cm}) ; \mathrm{d}_{\mathrm{o}}=$ basic standard diameter $(25 \mathrm{~cm}) ; \beta=$ self-thinning maximum rate on the complete density stand.

In model 1 , the $\delta$ constant was determined by the initial stand density $\left(\mathrm{N}_{1}\right)$, the initial mean diameter $\left(\mathrm{d}_{1}\right)$ with the standard diameter of $25 \mathrm{~cm}\left(\mathrm{~d}_{\mathrm{o}}\right)$, as in the following expression:

$\delta=\left(S_{f} / N_{1}\right)^{\gamma}-\left(d_{1}-d_{0}\right)^{\beta_{\gamma}}$

Where: $\mathrm{Sf}=$ maximum stand density index; $\mathrm{N}_{1}=$ initial stand density; $\gamma=$ self-thinning index; $\mathrm{d}_{1}=$ initial mean diameter; $\mathrm{d}_{\mathrm{o}}=$ basic standard diameter $(25 \mathrm{~cm})$; $\beta=$ self-thinning maximum rate on the complete density stand.

The competition zones were traced indicating the limits of the development stages for a specific stand density and mean diameter. Thus, based on the model by Tang (Tang, Meng and Meng, 1994), the growth zones were defined according to the maximum current annual increment in diameter, between the ages 14 and 15 years, and densities 12.5 and $25 \%$, characterizing the competition-free growth zone, the increased competition zone between relative densities 25 and $50 \%$, and the imminent mortality zone between relative densities 50 and 100\% (Schneider et al., 2011).

In order to estimate tree ages, which allowed to define the correct age for the thinning procedure for Eucalyptus grandis, the following equation was used:

$\mathrm{I}=\exp \left(\beta_{0}+\beta_{1} \cdot \ln (d)+\beta_{2} \cdot \ln \left(H_{d o m}\right)+\beta_{3} \cdot \ln (N)\right)$

Where: $\mathrm{I}=$ age in years; $\mathrm{d}=$ diameter at breast height $(1.30)$, in $\mathrm{cm} ; \mathrm{h}_{\mathrm{dom}}=$ dominant height, in $\mathrm{m} ; \beta=$ model coefficient; $\mathrm{N}=$ number of trees per hectare.

Model of stem form:

The cubage data measured by diameter class and amplitude between 10 and $60 \mathrm{~cm}$, provided the relative diameters and heights for the adjustment of the model proposed by Hradetzky (1976). The adjustment was performed with the Stepwise selection procedure, by using the integer power of ten to represent the base of the tree, together with fractioned powers to represent the upper stem. The powers tested were 0.005, 0.09, 0.08, 0.07, 0.06, 0.05, 0.04, 0.03, 0.02, 0.01, 0.9, 0.8, 0.7, 0.6, $0.5,0.4,0.3,0.2,0.1,1,2,3,4,5,10,15,20$ and 25 .

The usable stem was optimized to preferably form logs with the highest diameter and length, and the remaining part of the stem was classified in the slightly inferior classes, with lower length. The stem whose diameter was lower than $8 \mathrm{~cm}$ with bark, together with the stem part that did not form a log was considered residual volume. Assortments were calculated by the selected integrate function of stem form, which was defined by the Hradetzky polynomial function. The integrate function of stem form generated the estimated value of the whole stem or its parts, according to the informed minimum diameter, according to the function:

$\mathrm{V}_{\mathrm{t}}=\mathrm{K} \cdot\left(\int_{0}^{\mathrm{X}_{2}} \mathrm{Y}^{2} \cdot \mathrm{d}_{\mathrm{X}_{2}}-\int_{0}^{\mathrm{X}_{1}} \mathrm{Y}^{2} \cdot \mathrm{d}_{\mathrm{X}_{1}}\right)$

Where: $V_{t}=\log$ volume in $\mathrm{m}^{3} ; \mathrm{K}=\pi / 40000 ; \mathrm{X}_{1}=$ height in the beginning of the $\log (\mathrm{m}) ; \mathrm{X}_{2}=$ height at the end of the log (m).

The volume obtained by integrate is always a section, therefore, the total stem volume is between the top and the base of the tree. All the same, the volume of an assortment is between the end and the beginning of its section. To estimate relative heights $\left(\mathrm{h}_{\mathrm{i}}\right)$ corresponding to the minimum diameter of assortments, the adjustment of the fifth-degree polynomial with dependent variable $\left(\mathrm{h}_{\mathrm{i}} / \mathrm{h}\right)$ and the monomials as independent variables $\left(\mathrm{d}_{\mathrm{i}} / \mathrm{DBH}\right)$, with powers between first and fifth degrees were used. This procedure was performed to facilitate the quantification of wood assortments.

\section{Specification of Cost and Revenue Parameters:}

To determine costs, the operational procedures of technical activities used for the formation, establishment and conduction of forest stands were standardized. For this purpose, we initially defined the manual and mechanized operations of all activities performed in a forest enterprise established as standard with an initial spacing of $3 \times 2 \mathrm{~m}$. Also, the regional costs of human resources involved in the activities of a forest enterprise were surveyed, as well as implementation and maintenance costs in their respective years of occurrence. Due to the data being obtained in different times, they were corrected by the inflation (IGP-DI June 2017).

In order to determine the economic value, the price of standing wood $\left(\mathrm{R} \$ / \mathrm{m}^{3}\right)$ was considered, based on the market values of south Brazil, differentiated in types of wood assortments for use in energy, cellulose and/or wood shavings, sawmill or lamination. The assortment prices were obtained according to the "Radar Poyry Management Consulting" price report $\left(4^{\text {th }}\right.$ trimester 2014$)$, adapted by Marangon $(2015)$. The wood assortments defined were S1 $=1$ length $3 \mathrm{~m}$ and minimum diameter $>=33 \mathrm{~cm}$, estimated in R $\$ 80.00 ; \mathrm{S} 2=$ length $2.65 \mathrm{~m}$ and minimum diameter between $23-33 \mathrm{~cm}$, estimated in R $\$ 70.00 ; \mathrm{S} 3=$ length of $2.4 \mathrm{~m}$ and minimum diameter between 6-23 cm, estimated in R\$55.00; S4 = length of $1.5 \mathrm{~m}$ and minimum diameter between $8-16 \mathrm{~cm}$, estimated in R $\$ 38.00$; RES = remaining stem length and minimum diameter $<8 \mathrm{~cm}$, estimated in $\mathrm{R} \$ 15.00$. 
Citation: Gabriel Paes Marangon, Paulo Renato Schneider, Emanuel Arnoni Costa, Terezinha Bezerra Albino Oliveira, Jorge Antônio de Farias, César Augusto Guimarães Finger, 2018. Economic viability of different management regimes for Eucalyptus grandis W. Hillstands. Australian Journal of Basic and Applied Sciences., 12(5): 39-46.

For the economic analysis of the forest management regimes, we used methods considering the variation of the capital value in time, which is necessary to update the cash flows that occurred in different dates (Rezende and Oliveira, 2011). In this study, the discount rate was used to update financial flows, the Minimum Attractive Rate (MAR) of $5.65 \%$ per annum, since it is a percentage used by funding agencies for reforestation investments. The MAR is the interest rate that represents the opportunity cost or the alternative payment of the capital to be invested in forestation operations per hectare of eucalyptus.

Based on Silva et al. (2005), Souza and Clemente (2009), Rezende and Oliveira (2011), the following methods of economic analysis were adopted in this study: $a$ ) Internal Rate of Return (IRR); $b$ ) Net Present Value (NPV); $c$ ) Annualized Net Present Value (ANPV); $d$ ) Benefit-Cost Ratio (BCR); and $e$ ) Profitability Index (PI).

\section{a) Internal Rate of Return (IRR):}

It is the annual rate of return of the invested capital. It can be considered the potentiality of the project to generate returns, since it will only be viable when the IRR is higher than the Minimum Attractive Rate (MAR). This rate can be found based on the following expression:

$\left\{R_{r}+\sum D_{j} \cdot(1+i)^{r-j}\right\}=\left\{C \cdot(1+i)^{r}+\frac{a+t}{i} \cdot\left[(1+i)^{r}-1\right]\right\}=0$

Where: $\mathrm{Rr}=$ revenue of the final cut at age $\mathrm{r} ; \mathrm{Dj}=$ revenue of thinning performed at year $\mathrm{j} ; \mathrm{C}=$ implementation cost; $\mathrm{a}=$ annual administration cost; $\mathrm{r}=$ rotation, in years; $\mathrm{t}=$ annual cost of land lease or capital; $\mathrm{i}=$ annual interest rate.

b) Net Present Value (NPV):

Considered one of the most important indicators to measure financial viability of an investment project, NPV is the difference between the invested value and the expected profits, discounted at an initial date, using the MAR as the discount rate. The NPV can be calculated with the following expression:

$N P V=\sum_{j=0}^{n} \frac{R_{j}}{(1+i)^{j}}-\sum_{j=0}^{n} \frac{I_{j}}{(1+i)^{j}}-\sum_{j=0}^{n} \frac{C_{j}}{(1+i)^{j}}$.

Where: "R" = expected profits; "i" = annual interest rate; "n" = planning horizon; "j" = year; and "C" = invested capital.

c) Annualized NPV (ANPV):

This procedure consists of obtaining the NPV of the original cash flow and turning it into another equivalent cash flow, with characteristics of a uniform series. ANPV, also known as Equivalent Uniform Annual Cost, is calculated with the following expression:

$A N P V=\left[N P V \cdot i \cdot(1+i)^{n}\right] /\left[(1+n)^{n}-1\right]$

Where: "NPV" = net present value; "i" = annual interest rate; and " $\mathrm{n}$ " = planning horizon.

The importance to use the ANPV is to allow the selection of projects that have different lengths, since the equivalent values obtained per period implicitly correct the differences of horizon (Rezende and Oliveira, 2011).

d) Benefit-Cost Ratio (BCR):

With this index, the quotient between the present total revenues and the present total costs are calculated, both discounted from the MAR. The BCR can be calculated by the following expression:

$B C R=\sum_{t=0}^{n} \frac{R_{t}}{(1+i)^{t}} \div \sum_{t=0}^{n} \frac{C_{t}}{(1+i)^{t}}$

Where: " $n$ " = planning horizon;"Rt" = predicted revenues, and "Ct" = capital to be invested, both in different times " $\mathrm{t}$ " and divided by a discount factor $(1+\mathrm{i})$, where " $i$ " is the MAR (annual interest rate).

e) Profitability Index:

The profitability index is a method that considers the ratio between the net present value of the investment (CF) and the initial value of the investment (I0) for a given discount rate. The PI method can be expressed as follows:

$P I=\sum_{t=0}^{n} \frac{C F_{t}}{(1+i)^{t}} \div \mathrm{I} 0$

Where: "CFt" = total cash flow disregarding MAR divided by the discount factor $(1+\mathrm{i})^{\mathrm{t}}$. As the expression above shows, the project will be recommended every time the PI is above 1 and rejected when the PI is lower than 1 . Therefore, the higher the index, the more attractive the investment.

\section{Statistical analyses:}

All adjustments and statistics were processed in the Statistical Analysis System - SAS V. 9.1 (Sas, 2007). In order to assess the adjustment performance and the precision of models, the statistics of the adjusted coefficient of determination ( $\mathrm{R}^{2} \mathrm{adj}$.), the standard error of the estimate in percentage (RMSE) and, concomitantly, the graphical residual analysis, were used.

\section{RESULTS AND DISCUSSION}

Adjusted models:

The regression coefficients estimated for the model of Tang, Meng and Meng (1994), used to estimate tree density per hectare according to the mean diameter, were significant since their $\mathrm{R}^{2}$ adj. and RMSE\% were 0.744 and $3.17 \%$ (Equation 10), respectively, thus allowing to define the self-thinning line for Eucalyptus grandis.

$\ln (\mathrm{N})=\ln 978.23-\frac{1}{10.9237} \cdot \operatorname{Ln}\left[\left(\frac{\mathrm{d}-\mathrm{d}_{1}}{25}\right)^{1.6847^{* 10.9237}}+\left(\frac{978.23}{\mathrm{~N}_{1}}\right)^{10.9237}\right]$

Where: $\mathrm{d}=$ mean diameter of trees; $\mathrm{N}=$ number of trees per hectare; $\mathrm{N}_{1}=$ initial stand density; and $\mathrm{d}_{1}=$ initial mean diameter.

The regression coefficients were significant for the equation of tree age estimate, whose $\mathrm{R}^{2}$ aj. and RMSE\% were 0.821 and $16.17 \%$ (Equation 11 ), respectively, allowing to define the correct thinning age for Eucalyptus grandis.

$\mathrm{I}=\exp \left(-5.68386+0.89303 \times \ln (D B H)+1.18654 \times \ln \left(h_{d o m}\right)+0.13788 x \ln (N)\right.$

Where: $\mathrm{I}=$ age in years; $\mathrm{DBH}=$ diameter at breast height $(1.30)$, in centimetres; $\mathrm{h}_{\mathrm{dom}}=$ dominant height, in meters; and $\mathrm{N}=$ number of trees per hectare. 
Citation: Gabriel Paes Marangon, Paulo Renato Schneider, Emanuel Arnoni Costa, Terezinha Bezerra Albino Oliveira, Jorge Antônio de Farias, César Augusto Guimarães Finger, 2018. Economic viability of different management regimes for Eucalyptus grandis W. Hillstands. Australian Journal of Basic and Applied Sciences., 12(5): 39-46.

The Hradetzky model with integer and fractioned powers selected with the Stepwise procedure, used to estimate wood assortment, showed $\mathrm{R}^{2} \mathrm{adj} .=0.985$ and RMSE\% $=8.43 \%$ (Equation 12).

$$
\frac{\mathrm{d}_{\mathrm{i}}}{\mathrm{DBH}}=17.3861-0.0689\left(\frac{\mathrm{h}_{\mathrm{i}}}{\mathrm{h}}\right)-0.5979\left(\frac{\mathrm{h}_{\mathrm{i}}}{\mathrm{h}}\right)^{2}-16.6195\left(\frac{\mathrm{h}_{\mathrm{i}}}{\mathrm{h}}\right)^{0.005}-0.0994\left(\frac{\mathrm{h}_{\mathrm{i}}}{\mathrm{h}}\right)^{10}
$$
meters.

Where: $d_{i}=$ diameter at height $i$, in centimetres; DBH = diameter at breast height (1.30), in centimetres; $h_{i}=$ height at position $i$, in meters; $h=$ total height, in

The fifth-degree polynomial to estimate relative heights $\left(\mathrm{h}_{\mathrm{i}}\right)$, corresponding to minimum diameters of assortments, also had all significant regression coefficients and $\mathrm{R}^{2} \mathrm{adj} .=0.878$ and $\mathrm{RMSE} \%=9.70 \%$ (Equation 13 ).

$$
\frac{h_{i}}{h}=1.0820-1.7923\left(\frac{d_{i}}{D B H}\right)+5.8273\left(\frac{d_{i}}{D B H}\right)^{2}-11.9121\left(\frac{d_{i}}{D B H}\right)^{3}+9.2360\left(\frac{d_{i}}{D B H}\right)^{4}-2.3713\left(\frac{d_{i}}{D B H}\right)^{5}
$$

Where: $h_{i}=$ height at position $i$, in meters; $h=$ total height, in meters; $d_{i}=$ diameter at height $i$, in centimetres; DBH $=$ diameter at breast height $(1.30)$, in centimetres.

\section{Maximum density lines and management zones:}

By using the model by Tang, Meng and Meng (1994), the tree densities per hectare according to the mean stand diameter were generated, and the decreasing curve of maximum tree density per hectare (Line A) according to the mean diameter was obtained. This curve is usually called maximum density, since it represents the maximum tolerance to competition by trees. From this point, they start to be intolerant to competition and die, what characterizes self-thinning, generally having an impact on trees of lower sociological positions. Self-thinning is represented by the dimension of the mean diameter of a stand, which is conditioned by the initial spacing used in the stand implementation and determines the early mortality of trees due to competition. In view of this, tree densities per hectare according to the mean diameter were generated using the model by Tang, Meng and Meng (1994), with the parameters obtained with the data of reduced spacing.

Competition zones were delineated to indicate the limits of the stages of development for a given stand density for a specific mean diameter in a given time, based on the model by Tang and the growth zones defined by Schneider et al. (2011). Therefore, the density limits per hectare according to the mean diameter were delineated (Figure 1), where line A $(100 \%)$ represents the maximum density per diameter endured by the stand. Line B indicates the early mortality due to competition for water, light, nutrients, and living space in the stand. Line $\mathrm{C}$ indicates the beginning of maximum wood production of the stand. On the other hand, between lines $\mathrm{B}$ and $\mathrm{A}$ the stand is overstocked, a situation of unwanted management due to tree mortality. Between lines C and D there is a situation of tree density management that allows a full stand stocking, therefore, it is an optimal situation and desired for forest management. Below line D, there is a stand condition making it not possible to reach maximum use of soil, and line E established a stand condition with a very low stocking, with competition-free trees.

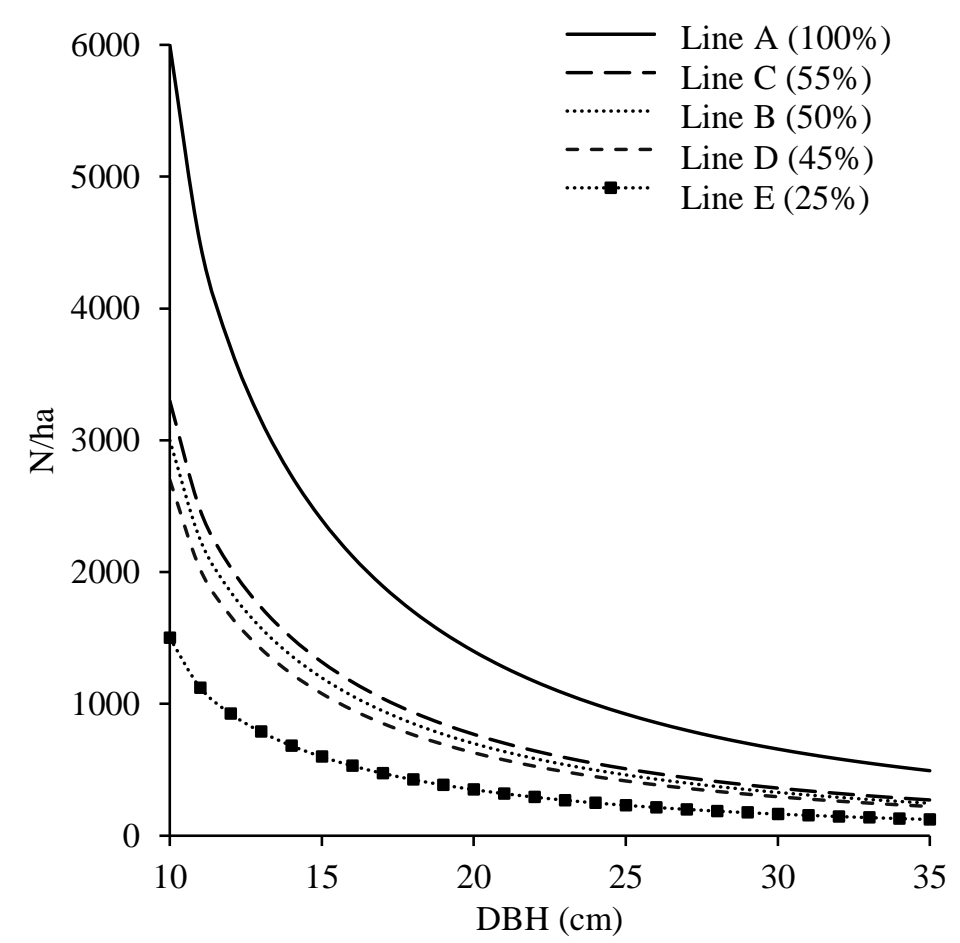

Fig. 1: Limit of the competition stages between individuals according to tree density by mean diameter in an arithmetic unit, where: Line A (full line $100 \%$ ) maximum density; Line B - early mortality (50\%); Line C - lower limit of maximum stand productivity (55\%); Line D - upper limit of maximum productivity $(45 \%)$; Line $\mathrm{E}$ - condition with a very low stocking, competition-free trees $(25 \%)$.

\section{Wood assortments:}

While working with Pinus taeda in Paraná and Santa Catarina, Kohler (2013) obtained the model of integer and fractioned powers with five and six independent variables, respectively, for each state, with the model selected for both study areas to achieve estimates of diameters along tree stems. However, Miguel et al. (2011), while working with Eucalyptus urophylla in Goiás, also selected the Hradetzky model with four variables.

On the other hand, Müller (2004), during a study of stem form for Eucalyptus grandis, and Thomas (2013), while working with Eucalyptus saligna, used the fifth-degree polynomial, as in the current study, with favourable statistics for estimates of relative heights corresponding to the minimum diameters of assortments. 
Citation: Gabriel Paes Marangon, Paulo Renato Schneider, Emanuel Arnoni Costa, Terezinha Bezerra Albino Oliveira, Jorge Antônio de Farias, César Augusto Guimarães Finger, 2018. Economic viability of different management regimes for Eucalyptus grandis W. Hillstands. Australian Journal of Basic and Applied Sciences., 12(5): 39-46.

The model integration generated the volume of the whole stem or its parts, according to the informed minimum diameter. For the adequate use of logs produced in the stand, they were divided into four assortments and residue, each with a specific market value. Relative heights were obtained for the diameters of $8 \mathrm{~cm}$ with bark, corresponding to the minimum usable diameter, and 16,23 and $33 \mathrm{~cm}$ in a table of assortments calculated for stems of individual trees with DBH from 8 to 52 $\mathrm{cm}$.

The set of adjusted equations allowed the elaboration of different scenarios, where the forest assortments at ages 8,10 and 12 years, and the migrations of volume per hectare, with the respective prognoses of wood volume in time, were explained (Figure 2).

S4 showed a higher use at 8 years of age and greater cumulative volumetric productivity, being these values close to the ones found for 12 years, even for the residue. At 10 years, the lowest productivity of the three analyzed ages was observed, but with a higher use of logs. S4 showed a gradual and proportional use of volumes along time, thus, the age of 12 years provided greater volumetric productivity and log use. S2 provided small uses for 8 years and approximate values of cumulative volumes for 10 and 12 years, which incorporated the highest number of logs. S1, on the other hand, showed very low values only for 12 years and for larger diameters with the use of two logs.

The age of 12 years showed higher productivity per hectare, and the distribution of volume in assortment classes were: $\mathrm{S} 1(>30 \mathrm{~cm})=0.0173 \mathrm{~m}^{3} \cdot \mathrm{ha}^{-1} ; \mathrm{S} 2(23-$ $33 \mathrm{~cm})=122.5 \mathrm{~m}^{3} \cdot \mathrm{ha}^{-1} ; \mathrm{S} 3(16-23 \mathrm{~cm})=206.2 \mathrm{~m}^{3} \cdot \mathrm{ha}^{-1} ; \mathrm{S} 4(8-16 \mathrm{~cm})=87.1 \mathrm{~m}^{3} \cdot \mathrm{ha}^{-1}$, and the top volume or residue was $(<8 \mathrm{~cm})=10.3 \mathrm{~m}^{3} \cdot \mathrm{ha}^{-1}$, with the highest use at 12 years in assortments S3 and S2 for process (firewood and cellulose) and sawmill (sawn industry), respectively.

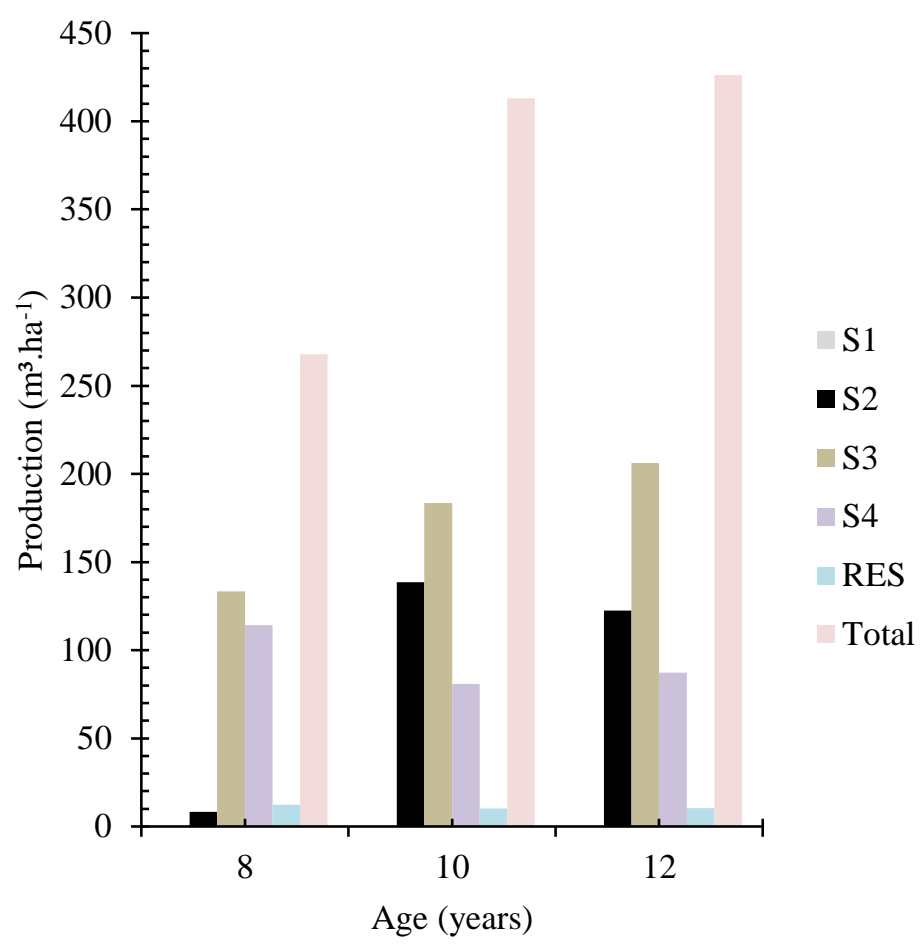

Fig. 2: Assortments by productivity and total representation for 8, 10 and 12 years for Eucalyptus grandis in Rio Grande do Sul.

Management regimes:

Management regimes can be planned for the stand from the specification of the initial density and spacing. In this example, three management regimes were simulated with different interventions until the final cutting for the density limits established with the adjusted model of Tang, Meng and Meng (1994) (Figure 3). 
Citation: Gabriel Paes Marangon, Paulo Renato Schneider, Emanuel Arnoni Costa, Terezinha Bezerra Albino Oliveira, Jorge Antônio de Farias, César Augusto Guimarães Finger, 2018. Economic viability of different management regimes for Eucalyptus grandis W. Hillstands. Australian Journal of Basic and Applied Sciences., 12(5): 39-46.
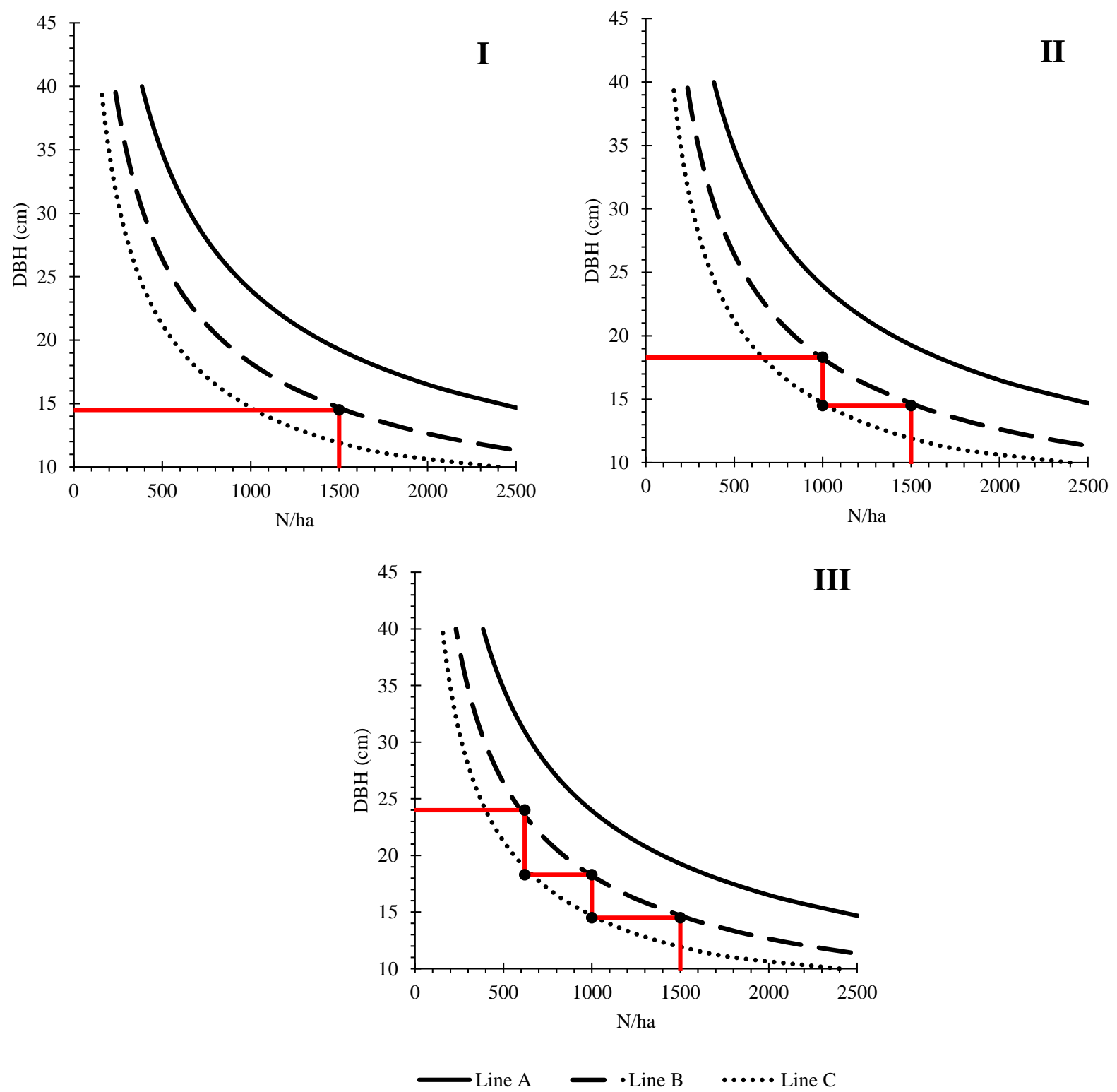

Fig. 3: Management regimes: (I) trajectory of stand with the growth of mean diameter according to tree density without thinning; (II) with one thinning at 52.8 months and clear-cutting at 85.4 months; (III) with two thinning's; at 52.8 and 85.4 months, and clear-cutting at 121.8 months for Eucalyptus grandis, in Rio Grande do Sul.

Management regime I (MR I): Stand conducted without thinning and clear-cutting at 52.8 months:

By simulating the management of Eucalyptus grandis, with a planting density of 1,666 trees per hectare, discounting the early mortality of $10 \%$ according to the average mortality data, the density of 1,500 trees per hectare and mean diameter of $14.5 \mathrm{~cm}$ were established. With the strategy to not perform thinning, the nonoccurrence of mortality by self-thinning until that moment (Figure $3-\mathrm{I}$ ) is observed, since the development of mean diameter for tree density per hectare is below Line B, what indicates mortality. In this case, the simulation was demonstrated as a stand with diameter $14,5 \mathrm{~cm}$ without mortality, has clear-cutting at 52.8 months, what results in 1,500 trees per hectare and a production of $250.8 \mathrm{~m}^{3} \cdot \mathrm{ha}^{-1}$.

Management regime II (MR II): Stand conducted with thinning at 52.8 months and clear-cutting at 85.4 months:

Based on the previous regime, management regime II considers thinning when the mean diameter reaches approximately $14.5 \mathrm{~cm}$ (Line B, early mortality), the cutting of 500 trees per hectare is performed, and the stand will contain 1000 trees per hectare (Line C of Figure 3 - II). In this case, the stand grows competitionfree, later approximating to Line B (early mortality) again, reaching the mean diameter of $18.3 \mathrm{~cm}$. According to the regime concerned, the production of 413.3 $\mathrm{m}^{3} \cdot \mathrm{ha}^{-1}$ is obtained, this time with clear-cutting (Figure $3-$ II).

Management regime III (MR III): stand conducted with thinning at 52.8 and 85.4 months; and clear-cutting at 121.8 months:

The management regime III established similarly to regime II had a second thinning performed and the cutting of 380 trees per hectare, re-establishing the forest growth space until reaching Line B again with mean diameter of $24.0 \mathrm{~cm}$, with 620 trees per hectare. In the clear-cutting, $461.7 \mathrm{~m}^{3} . \mathrm{ha}^{-1}$ were produced (Figure $3-$ III). 
Citation: Gabriel Paes Marangon, Paulo Renato Schneider, Emanuel Arnoni Costa, Terezinha Bezerra Albino Oliveira, Jorge Antônio de Farias, César Augusto Guimarães Finger, 2018. Economic viability of different management regimes for Eucalyptus grandis W. Hillstands. Australian Journal of Basic and Applied Sciences., 12(5): 39-46.

Management regimes and stand density before and after thinning and clear-cutting:

According to each management regime performed, wood assortments per hectare were generated with the Hradetzky model (12). The values of Table 1 show the variation of production according to the management regimes established, with differences in the number of thinning's and the period of final cutting. The same has occurred with the volume of assortment classes, with the introduction of wood in the higher assortment classes according to the increase in number of thinning's performed.

Table 1: Management regimes without thinning, with one and two thinning, clear-cutting, and their production of Eucalyptus grandis in Rio Grande do Sul.

\begin{tabular}{|c|c|c|c|c|c|c|c|c|c|c|}
\hline \multirow{2}{*}{ Operation } & \multirow{2}{*}{ Age (months) } & \multirow{2}{*}{$\mathrm{DBH}(\mathrm{cm})$} & \multirow{2}{*}{$\mathrm{h}(\mathrm{m})$} & \multirow{2}{*}{$\mathrm{N}$ (ha) } & \multirow{2}{*}{$\mathrm{V}\left(\mathrm{m}^{3} \cdot \mathrm{ha}^{-1}\right)$} & \multicolumn{5}{|c|}{ Assortments $\left(\mathrm{m}^{3} \cdot \mathrm{ha}^{-1}\right)$} \\
\hline & & & & & & $\mathrm{S} 1$ & $\mathrm{~S} 2$ & S3 & $\mathrm{S} 4$ & RES \\
\hline No thinning & 52.8 & 14.5 & 19.8 & 1500 & 250.8 & 0.0 & 0.0 & 22.3 & 200.1 & 28.4 \\
\hline Thinning & 52.8 & 14.5 & 19.8 & 500 & 83.6 & 0.0 & 0.0 & 7.4 & 66.7 & 9.5 \\
\hline Clear-cutting & 85.4 & 18.3 & 25.3 & 1000 & 413.3 & 0.0 & 19.8 & 213.5 & 163.6 & 16.5 \\
\hline Thinning & 52.8 & 14.5 & 19.8 & 500 & 83.6 & 0.0 & 0.0 & 7.4 & 66.7 & 9.5 \\
\hline Thinning & 85.4 & 18.3 & 25.3 & 380 & 157.0 & 0.0 & 7.5 & 81.1 & 62.2 & 6.3 \\
\hline Clear-cutting & 121.8 & 24.0 & 31.3 & 620 & 461.7 & 0.0 & 154.6 & 204.9 & 91.3 & 11.0 \\
\hline
\end{tabular}

Where: $\mathrm{DBH}=$ diameter at breast height $(\mathrm{cm}) ; \mathrm{h}=$ total height $(\mathrm{m}) ; \mathrm{N}=$ number of trees per hectare; V = total volume $\left(\mathrm{m}^{3}\right.$. ha $\left.{ }^{-1}\right) ;$ and $\mathrm{S} 1, \mathrm{~S} 2, \mathrm{~S} 3, \mathrm{~S} 4, \mathrm{RES}=\mathrm{forest}$ assortments and residues $\left(\mathrm{m}^{3}\right.$ per hectare).

\section{Economic Assessment:}

The economic assessment of the culture of eucalyptus is seen as very relevant since this activity requires high investments and the returns from the invested capital are achieved in the long term. However, according to Souza and Clemente (2009), Rezende and Oliveira (2011), no economic and financial index should be analyzed separately, being necessary that different indicators show the economic viability of the regime. Thus, in order to assess the expected returns of the different management regimes for the culture of eucalyptus, the results of indicators Net Present Value, Annualized Net Present Value, Internal Rate of Return, Benefit-Cost Ratio and Profitability Index of the three management regimes are described (Table 2).

Table 2. Economic indicators applied to different management regimes for Eucalyptus grandis in Rio Grande do Sul.

\begin{tabular}{|c|c|c|c|}
\hline \multirow[b]{2}{*}{ Economic Indicators } & MR I & MR II & MR III \\
\hline & Cut at 52.8 months & $\begin{array}{l}\text { Thinning at } 52.8 \text { months } \\
\text { and cut at } 85.4 \text { months }\end{array}$ & $\begin{array}{l}\text { Thinning at } 52.8 \text { and } 85.4 \\
\text { months and cut at } 121.8 \text { months }\end{array}$ \\
\hline Present Value of Investment Cash Flow & $6,283.56$ & $7,592.31$ & $8,635.53$ \\
\hline Present Value of Profit Cash Flow & $6,366.47$ & $15,668.54$ & $22,179.52$ \\
\hline Net Present Value - NPV (R\$) & 82.91 & $8,076.23$ & $13,544.00$ \\
\hline Annualized Net Present Value - ANPV (R\$) & 65.10 & $5,496.95$ & $7,817.21$ \\
\hline Internal Rate of Return - IRR (\%) & 0.45 & 16.12 & 16.55 \\
\hline Benefit-Cost Ratio - BCR & 1.01 & 2.06 & 2.57 \\
\hline Profitability Index - PI & 0.01 & 1.06 & 1.57 \\
\hline
\end{tabular}

As shown in Table 2, all regimes showed positive economic indicators. However, MR I was almost on the balance point line between investments and profits. When analyzed by the NPV and ANPV, this regime shows results of R $\$ 82.91$ e $\mathrm{R} \$ 65.10 \mathrm{ha}^{-1}$, respectively, the latter when the cash flow is transformed into a uniform array. Regarding the Benefit-Cost Ratio, it was observed that for each R $\$ 1.00$ invested the return will be only R $\$ 1.01$. Also, it was evidenced that MR I - with clearcutting only at 52.8 months - had a Profitability Index of 0.01. This index resulted from the ratio between NPV and Present Value of Investment Cash Flow, and this result means that there will be profit of only $\mathrm{R} \$ 0.01$ for each $\mathrm{R} \$ 1.00$ invested (per planted hectare), thus making it more vulnerable to future risks.

When analyzing the Internal Rate of Return (IRR), whose purpose is to be the discount rate that equals the present value of future revenues to the present value of future costs (Rezende and Oliveira, 2008) making the NPV null, it is possible to affirm that MR I, even though showing positive results, does not provide profitability, because the invested capital will generate returns of only $0.45 \%$, nor safety, because the IRR is also used as a risk measure, as stated by Souza and Clemente (2009).

MR III (with thinning at 52.8 and 85.4 months and clear-cutting at 121.8 months) stands out as the most attractive among the regimes analyzed, since it showed the highest economic indicators. When analysing NPV and ANPV, it was observed that, according to the minimum attractive rate (MAR) considered for the study, the profits obtained paid off all the investments, and a return of $\mathrm{R} \$ 13,544.00$ and $\mathrm{R} \$ 7,817.21$ per hectare, respectively, was achieved. When compared to the other management regimes, MR III has shown to be the safest and more profitable, with the IRR above $16 \%$ per annum.

The results found in this study differed from the ones found by Thomas (2013), who performed the economic assessment for a eucalyptus stand in a regime of high-growing trees with thinning, where he verified that this regime is economically viable, increasing the values together with the increase of rotation and the number of thinning's. The author verified that the economically optimal rotation occurred earlier in the best sites than in the worst ones. He also observed that the management regime with rotation of 14 years (168 months) performed with two thinning's, and clear-cutting at the end of the rotation, implemented in a site with highly-productive potential, was the simulation with the highest economic return, producing an annual NPV of R $\$ 1,791.00$ ha $^{-1}$ and IRR of $21.24 \%$ per annum.

It corroborates the ANPV criteria that has also indicated MR III as the one with the best economic viability compared to the other regimes that, except for MR I, also had IRR values higher than the discount rate used. Considering the BCR indicator, results showed that MR III also provided a relatively higher financial return, with revenues over $157 \%$ higher than investments, both discounted at a pre-established minimum attractive rate. Similarly, the result of the profitability index for this management regime was $57 \%$, what means that for each $\mathrm{R} \$ 1.00$ invested there would be a profit of $\mathrm{R} \$ 1.57$ or $57 \%$.

The profitability of forest investments has already been proven for the mesoregions of Rio Grande do Sul in the study performed by Schneider (2006). In another analysis, BRDE (2012) evidenced the economic viability of forestation of three species, where Acacia mearnsii De Wild. achieved an Internal Rate of Return of $31.62 \%$ per annum. Eucalyptus managed for sawmill showed an IRR of $27.78 \%$ per annum with clear-cutting at 12 years (144 months), and when managed for cellulose and energy, the IRR was $25.22 \%$ p.a. with clear-cutting at 7 years ( 84 months), and finally Pinus with an IRR of $19.96 \%$ per annum with clear-cutting at 15 years (180 months). 
Citation: Gabriel Paes Marangon, Paulo Renato Schneider, Emanuel Arnoni Costa, Terezinha Bezerra Albino Oliveira, Jorge Antônio de Farias, César Augusto Guimarães Finger, 2018. Economic viability of different management regimes for Eucalyptus grandis W. Hillstands. Australian Journal of Basic and Applied Sciences., 12(5): 39-46.

Conclusion:

Investments in reforestation for Eucalyptus grandis under different management regimes provide economic returns, as expressed by the criteria ANPV, IRR, BCR and PI, where the greater the number of thinnings and the later the time for clear-cutting, the more attractive the investment.

The results allow to find the regulation of stand density of Eucalyptus grandis and by applying the relationships found, it was possible to build important tools such as the planning of silvicultural interventions to conduct stands.

\section{REFERENCES}

Afonso, M.H.F., J.V. Souza, S.R. Ensslin and L. Ensslin, 2011.Como construir conhecimento sobre o tema de pesquisa? Aplicação do processo PROKNOWC na busca de literatura sobre avaliação do desempenho sustentável. Revista de Gestão Social e Ambiental, 5(2): 47-62.

Alvares, C.A., J.L. Stape, P.C. Sentelhas, J.L. de M. Gonçalves and G. Sparovek, 2013 Köppen's climate classification map for Brazil. Meteorologische

Zeitschrift, 22: 711-728.

Bornia, A.C., 2009. Análise gerencial de custos: aplicação em empresas modernas. São Paulo, 2. ed.

Brde, 2011. Florestamento na região sul do Brasil: uma análise econômica. Retrieved from http://brde.com.br/estudoepub.pdf on 06 st Dec.

Campos, J.C.C. and H.G. Leite, 2013. Mensuração florestal: perguntas e respostas. Viçosa, 4 ed.

Farnden, C., 1996. Stand density management diagrams for lodgepole pine, white spruce and interior Douglas-fir. Information Report BC-X-360. Government of Canada, Department of Natural Resources, Canadian Forest Service, Pacific Forestry Centre, Victoria, BC.

Hradetzky, J., 1976. Analyse und interpretation statstisher abränger keiten. (Biometrische Beiträge zu aktuellel forschungs projekten). Baden: Württemberg Mitteilungen der FVA, pp: 146.

Kohler, S.V., 2013. Evolução do afilamento do tronco e do sortimento em plantios de Pinus taeda nos Estados do Paraná e Santa Catarina. Dissertação (Mestrado em Engenharia Florestal) - Universidade Federal do Paraná, Curitiba.

Marangon, G.P., 2015. Otimização bioeconômica do regime de manejo para Eucalyptus grandis W. Hill no estado do Rio Grande do Sul. 2015. Tese (Doutorado em Engenharia Florestal) - Universidade Federal de Santa Maria, Santa Maria.

Marion, J.C. and S. Segatti, 2012.Contabilidade da pecuária. São Paulo, 10 ed

Miguel, E.P., S. do A. Machado, A. Figueiredo Filho and J.E. Arce, 2011. Modelos polinomiais para representar o perfil e o volume do fuste de Eucalyptus urophylla na região norte do estado de Goiás. Floresta, 41(2): 355-368.

Müller, I., 2004. Forma de tronco e sortimentos de madeira para Eucalyptus grandis Hill ex Maiden., manejado em alto fuste, na região sudeste do estado do Rio Grande do Sul. Tese (Doutorado em Engenharia Florestal) - Universidade Federal de Santa Maria, Santa Maria.

Nogueira, G.S., P.L. Marshall, H.G. Leite and C.C. Campos, 2015. Thinning Intensity and Pruning Impacts on Eucalyptus Plantations in Brazil. International Journal of Forestry Research, Article ID 168390, 10 p. doi:10.1155/2015/168390.

Retslaff, F.A., A.F. Filho, S.A. Machado, J.E. Arce and E. Jaskiu, 2016. Diagrama de manejo da densidade para Pinus taeda no estado do Paraná. Floresta, 46(2): 185-195.

Rezende, J.L.P. and A.D. Oliveira, 2011. Análise Econômica e Social de Projetos Florestais. 389 p. Viçosa, 2.ed.

Sas Institute, 2014. SAS User's Guide: Statistics. PROC CAPABILITY and General Statements. Retrieved from http://www.asu.edu/sas/sasdoc/sashtml/qc/index.htm on 23 st Nov.

Scheeren, L.W., P.R. Schneider and C.A.G. Finger, 2004. Crescimento e produção de povoamentos monoclonais de Eucalyptus saligna Smith manejados com desbaste, na região sudeste do Estado do Rio Grande do Sul. Ciência Florestal, 14(2): 111-122.

Schneider, P.R.,C.A.G. Finger, P.S.P. Schneider, F.D. Fleig, C. Thomas and J.A. de Farias, 2011. Quociente do diâmetro pela área basal e zonas de competição em povoamento monoclonal de Eucalyptus saligna. Ciência Florestal, 21(4): 755-764.

Schneider, P.R., 2006. Rentabilidade em investimento florestal. Santa Maria, pp: 153.

Schneider, P.R., C.A.G. Finger, P.S.P. Schneider, F.D. Fleig and T.A. da Cunha, 2015. Influência do espaçamento no autodesbaste de povoamento monoclonal de Eucalyptus saligna Smith. Ciência Florestal, 25(1): 119-126.

Silva, M.L., L.A.G. Jacovine and S.R. Valverde, 2005. Economia Florestal. Viçosa, 2.ed.

Simioni, F.J and V.A. Hoeflich, 2006. Avaliação de Risco em Investimentos Florestais. Boletim de Pesquisas Florestais, (52): 79-92.

Souza, A. and A. Clemente, 2009. Decisões Financeiras e Análise de Investimentos: fundamentos técnicas e aplicações. São Paulo. 21-36.

Spiecker, H., 1983. Durchorstungsasatze bei Eiche unter besonderer Berucksichtigung des Dickenwachtums. Allgemeine Forstzeitschrift - u. J. - Ztg., 154(2):

Tang, S., C.H. Meng and F.R. Meng, 1994. A growth and self-thinning model for pure even-age stands: theory and applications. Forest Ecology and Management, (70): 67-73.

Thomas, C., 2013. Determinação bioeconômica do manejo em alto fuste de povoamentos monoclonais de Eucalyptus saligna Smith. Tese (Doutorado em Engenharia Floresal) - Universidade Federal de Santa Maria, Santa Maria.

Trouvé, R., C.R. Nitschke, A.P. Robinson and P.J. Baker, 2017. Estimating the self-thinning line from mortality data. Forest Ecology and Management, 402: 122-134. 